\title{
Phenotypic and genotypic characterization of S. aureus isolated from clinical and subclinical bovine mastitis
}

\section{Enany, M.E., Younes, S. *, AL gammal, A.M. Salem, M. ** and El Dieb, H.A.}

Department of Bacteriology, Immunology and Mycology, and **Department of Animal Medicine, Faculty of Veterinary Medicine, Suez Canal University and *Department of Clinical pathology, Faculty of Medicine, Suez Canal

\section{University}

\section{ABSTRACT}

In order to determine the prevalence of $\boldsymbol{S}$. aureus in clinical and subclinical bovine mastitis as well as the relationship between the presence of protein A gene and the udder inflammatory response . A total of 400 quarter milk samples were collected from 100 lactating Friesian cows at Ismailia Governorate. The percentage of clinical mastitis was ( $19.5 \%$.), while the percentage of subclinical mastitis according to C.M.T was ( $42.85 \%)$. The percentage of S.aureus in clinical mastitis was (28.2\%), while in in subclinical mastitis was $(22.46 \%)$ ). The identification of S,aureus was confirmed by PCR amplification of species-specific parts of the gene encoding the 16S rRNA. Twenty nine S.aureus isolates were subjected to PCR for detection of $X$ region of protein A (spA) gene, 10 isolates from clinical mastitis and 19 isolates subclinical mastitiC milk specimens (+++ve CMT and ++ve CMT) were $(100 \%)$ positive . Results indicate that there was a positive relationship between the presence of protein A gene of S.aureus and the inflammation of udder in clinical mastitis as well as the high grades of subclinical mastitis.

\section{INTRODUCTION}

Bovine mastitis is an important and a persistent infection in the bovine population producing economic losses; drop in milk production, increased cost of treatment and culling process (Singh and Bansal, 2004).

The major reservoirs of $\boldsymbol{S}$. aureus are found in infected udders, teat canals, and teat lesions, but these bacteria also have been located on teat skin, muzzles, and nostrils. The bacteria are spread to uninfected quarters by teat cup liners, milkers' hands, washcloths, and flies. Staphylococci do not persist on healthy teat skin but readily colonize damaged skin and teat lesions. The organisms multiply in infected lesions and result in increased chance of teat canal colonization and subsequent udder infection. Heifers infected during 
gestation that carry infections through calving represent an important reservoir from which $\boldsymbol{S}$. aureus can spread to uninfected herd mates. There is considerable debate surrounding the route of $\boldsymbol{S}$. aureus infection in heifers prior to first calving, but calves fed colostrum from an S.aureusinfected dam is a likely source.

(Petersson and Mullarky 2010)

$S$. aureus has a capacity to produce a large number of potential virulence factors, including a variety of exotoxins and cell surface-associated proteins (Fitzgerald et al, 2000; Foster, 2005; Kalorey et al, 2007). One of the major surface proteins is staphylococcal protein A (Spa), which bacterial cell wall product that binds immunoglobulin $\mathrm{G}$ and impairs opsonisation by serum complement and phagocytosis by polymorphonuclear leukocytes . The decrease of protein $\mathrm{A}$ on the cell surface of $\boldsymbol{S}$. aureus resulted in a greater number of free receptor sites for complement $\mathrm{C} 3 \mathrm{~b}$ and in an increase in phagocytosis. The gene encoding protein A $(s p a)$ is composed of some functionally distinct regions: IgG $\mathrm{Fc}$ binding region (spa- $\mathrm{IgG}$ ), $\mathrm{X}$ region (spa-X) and at $\mathrm{C}$ terminus, a sequence required for cell wall attachment. The repetitive region $\mathrm{X}$ of the spa gene includes a variable number of 24-bp repeats. The number and sequence of individual repeats may differ among strains. (Gao and Stewart, 2004)
The objective of this study was to determine the prevalence of S.aureus in bovine clinical and subclinical mastitis (using CMT and bacteriological examination), detection of protein $\mathrm{A}(\mathrm{spA})$ gene in clinical and subclinical mastitis milk samples as well as the relationship between the presence of protein A gene and the udder inflammatory response with different degrees.

\section{MATERIAL AND METHODS Milk samples}

A total of 400 milk samples were collected from apparently normal quarters (322 milk samples) and clinical cases of mastitis $\quad(78$ quarter milk samples) of 100 lactating Friesian cows from Ismailia Governorate.

California mastitis test (CMT)

Apparently normal milk samples were subjected to CMT (screening test) for the detection of subclinical mastitis. Milk samples with CMT scores (suspect \pm ),,+++ and +++ were prepared for bacteriological examination.

Isolation and identification of S.aureus:

Milk samples were collected from clinical mastitis quarter and positive C.M.T quarter milk samples were incubated aerobically for 24 hours at $37{ }^{\circ} \mathrm{C}$ to achieve potential bacterial growth and a loopfull was taken from each sample and streaked onto Nutrient agar, blood agar and Mannitol salt agar plates . All plates were incubated at $37^{\circ} \mathrm{C}$ 
for 24-48 hours and examined for bacterial growth. Bacterial colonies were identified morphologically using Gram's stain as well as biochemically using methods described by (Quinn et al, 1994).

\section{PCR detection of 16SrRNA gene} and the protein $A(\operatorname{spA})$ gene of S.aureus

Twenty nine isolates were subjected to PCR for detection of $16 \mathrm{~S}$ rRNA and spA genes.

1-Extraction of DNA from S.aureus isolates by boiling method according to (Van Eys et al, 1989)

\section{2-Polymerase chain reaction:}

DNA samples were tested in $50 \mu \mathrm{l}$ reaction volume in a $0.2 \mathrm{ml}$ PCR tube, containing PCR buffer ( 50 $\mathrm{mM} \mathrm{Kcl}, 10 \mathrm{mM}$ tris - $\mathrm{Hcl}, 1 \mathrm{mM}$ $\mathrm{Mgcl}_{2}$ ) each dNTPS ( Deoxy nucleotide Triphosphate ) $200 \mathrm{uM}$ each ( dATP , dGTP , dCTP and dTTP ), [ Two primer pairs each at 50 picomol / reaction ] and 0.5 of taq DNA polymerase. Thermal cycling in a programmable heating block (Coy vorporation, Grasslake, Michan, USA) was done. A negative control PCR reaction with no template also was included in this assay.16SrRNA primers were prepared as described by (Monday and Bohach, 1999), while spA gene primers were synthesized as described by (Akineden et al, 2001).

Table (1): list of primers used for PCR assay

\begin{tabular}{|c|c|c|c|}
\hline Primer & Primer Sequence. & $\begin{array}{c}\text { Molecular } \\
\text { weight (bp) }\end{array}$ & $\begin{array}{c}\text { Annealing } \\
\text { temp. }\end{array}$ \\
\cline { 1 - 2 } $\begin{array}{c}\text { 16S rRNA. } \\
\text { F }\end{array}$ & GTA GGT GGC AAG CGT TAT & \multirow{2}{*}{ CC } & \multirow{2}{*}{$64^{\circ} \mathrm{c}$} \\
\cline { 1 - 2 } $\begin{array}{c}\text { 16S rRNA. } \\
\text { R }\end{array}$ & CGC ACA TCA GCG TCA G & \\
\cline { 1 - 2 } spa-F & CAA GCA CCA AAA GAG GAA & $\begin{array}{c}140,270 \\
\text { and } 290\end{array}$ & \multirow{2}{*}{$\mathbf{6 0}^{\circ} \mathrm{c}$} \\
\hline spa-R & CAC CAG GTT TAA CGA CAT &
\end{tabular}

PCR Protocol: Initial

Denaturation at $94{ }^{\circ} \mathrm{C}$ for $4 \mathrm{~min}$, Denaturation at $94{ }^{\circ} \mathrm{C}$ for $1 \mathrm{~min}$, Annealing at $64{ }^{\circ} \mathrm{C}$ for $16 \mathrm{SrRNA}$ primer and $60{ }^{\circ} \mathrm{C}$ for (spA) gene primer for $1 \mathrm{~min}$, Extension at 72 ${ }^{\circ} \mathrm{C}$ for $1 \mathrm{~min}$. Cycles repeated for 39 times and proceeded by initial denaturation at $95^{\circ} \mathrm{C}$ for $5 \mathrm{~min}$. and followed by final extension at 72 for $10 \mathrm{~min}$.

3-Screening of PCR products: ten $\mu \mathrm{l}$ of amplified PCR product was analyzed by electrophoresis on a $2 \%$ agarose gel stained with $0.5 \mu \mathrm{g}$ of ethedium bromide / $\mathrm{ml}$. Electrophoresis was carried out in $1 \mathrm{X}$ TAE buffer at 80 volt for 1 hour. The gel was photographed in order to obtain a permanent record using UVP BioSpectrum Imaging Systems, UVP® LLC.

\section{RESULTS}

Incidence of clinical and subclinical mastitis in examined quarter 
Table (2): Prevalence of subclinical mastitis in examined quarter milk samples of cows according to California mastitis test (CMT)

\begin{tabular}{|l|l|l|l|l|}
\hline $\begin{array}{l}\text { No. of } \\
\text { examined milk } \\
\text { samples }\end{array}$ & $\begin{array}{l}\text { No. of +ve } \\
\text { CMT samples }\end{array}$ & $\begin{array}{l}\text { \% of +ve } \\
\text { CMT samples }\end{array}$ & $\begin{array}{l}\text { No. of -ve } \\
\text { CMT samples }\end{array}$ & $\begin{array}{l}\text { \% of -ve CMT } \\
\text { samples }\end{array}$ \\
\hline 322 & 138 & $42.85 \%$ & 184 & $57.14 \%$ \\
\hline
\end{tabular}

Table (3): The percentage of S.aureus isolated from clinical mastitis milk samples

\begin{tabular}{|l|l|l|l|l|l|l|}
\hline $\begin{array}{l}\text { Total clinical } \\
\text { mastitis milk of +ve } \\
\text { samples }\end{array}$ & $\begin{array}{l}\text { No. of +ve } \\
\text { samples for } \\
\text { S.aureus }\end{array}$ & $\begin{array}{l}\text { \% of } \\
\text { samples }\end{array}$ & $\begin{array}{l}\text { No. of of -ve } \\
\text { samples }\end{array}$ & $\begin{array}{l}\text { omples } \\
\text { samples }\end{array}$ \\
\hline 78 & 22 & $28.2 \%$ & 56 & $71.79 \%$ \\
\hline
\end{tabular}

Table (4) The percentage of S.aureus isolated from subclinical mastitis milk samples

\begin{tabular}{|c|c|c|c|c|}
\hline $\begin{array}{c}\text { Total subclinical } \\
\text { mastitis milk } \\
\text { samples }\end{array}$ & $\begin{array}{c}\text { No. of } \\
\text { S.aureus } \\
\text { isolates }\end{array}$ & $\begin{array}{c}\text { \% of S.aureus } \\
\text { isolates }\end{array}$ & $\begin{array}{c}\text { No. of other } \\
\text { bacterial } \\
\text { isolates }\end{array}$ & $\begin{array}{c}\text { \% of other } \\
\text { bacterial } \\
\text { isolates }\end{array}$ \\
\hline 138 & 31 & $22.46 \%$ & 107 & $77.536 \%$ \\
\hline
\end{tabular}

\section{PCR results:}

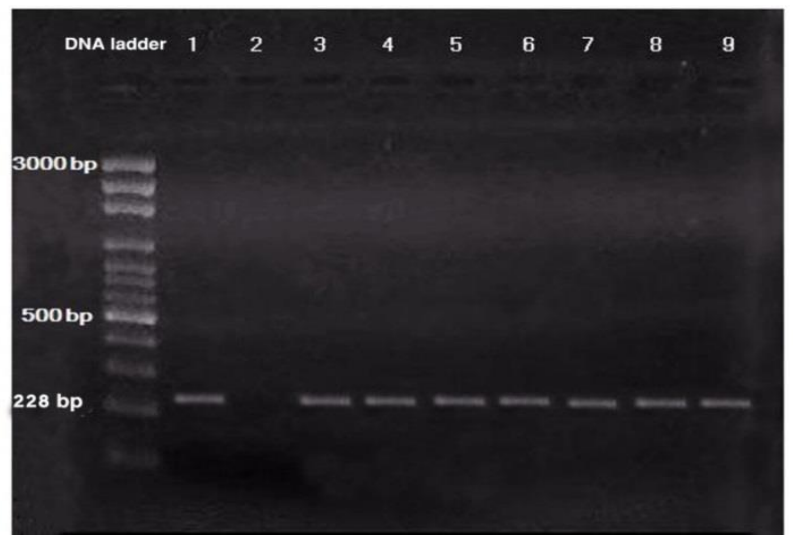

Fig. ( 1) illustrated the positive amplification of 228 bp fragment of $16 \mathrm{~S}$ rRNA gene from the extracted DNA of S.aureus isolates.

- $\quad$ (100 bp DNA ladder)

- Lane 1: control positive S.aureus strain according to

(EL-Gammal, 2011)

- Lane 2: control negative

- Lane 3-9: showed positive S.aureus isolates 
Table(5) :Prevalence of SPA gene in isolated S.aureus

\begin{tabular}{|c|c|c|c|c|}
\hline \multicolumn{5}{|c|}{10 from 22 clinical mastitis isolates } \\
\hline $\begin{array}{l}\text { No. of samples subjected to } \\
\text { PCR for SPA } \\
\text { gene detection }\end{array}$ & $\begin{array}{l}\text { No. of +ve } \\
\text { SPA gene }\end{array}$ & $\begin{array}{c}\% \text { of +ve SPA } \\
\text { gene }\end{array}$ & $\begin{array}{c}\text { No.-ve } \\
\text { SPA gene }\end{array}$ & $\begin{array}{l}\% \text { of .-ve } \\
\text { SPA gene }\end{array}$ \\
\hline 10 isolates from 22 & 10 isolates & $100 \%$ & 0 & $0 \%$ \\
\hline \multicolumn{5}{|c|}{19 from 31 subclinical mastitis isolates } \\
\hline $\begin{array}{l}\text { No. of samples subjected to } \\
\text { PCR for SPA } \\
\text { gene detection }\end{array}$ & $\begin{array}{l}\text { No. of +ve } \\
\text { SPA gene }\end{array}$ & $\begin{array}{c}\% \text { of +ve SPA } \\
\text { gene }\end{array}$ & $\begin{array}{l}\text { No.-ve } \\
\text { SPAgene }\end{array}$ & $\begin{array}{l}\% \text { of .-ve } \\
\text { SPA gene }\end{array}$ \\
\hline 5 isolates from $9+++$ ve CMT & 5 isolates & $100 \%$ & 0 & $0 \%$ \\
\hline 10 isolates from $18++$ ve CMT & 10 isolates & $100 \%$ & 0 & $0 \%$ \\
\hline All 4 isolates +ve CMT & 1 isolate & $25 \%$ & 3 isolates & $75 \%$ \\
\hline
\end{tabular}

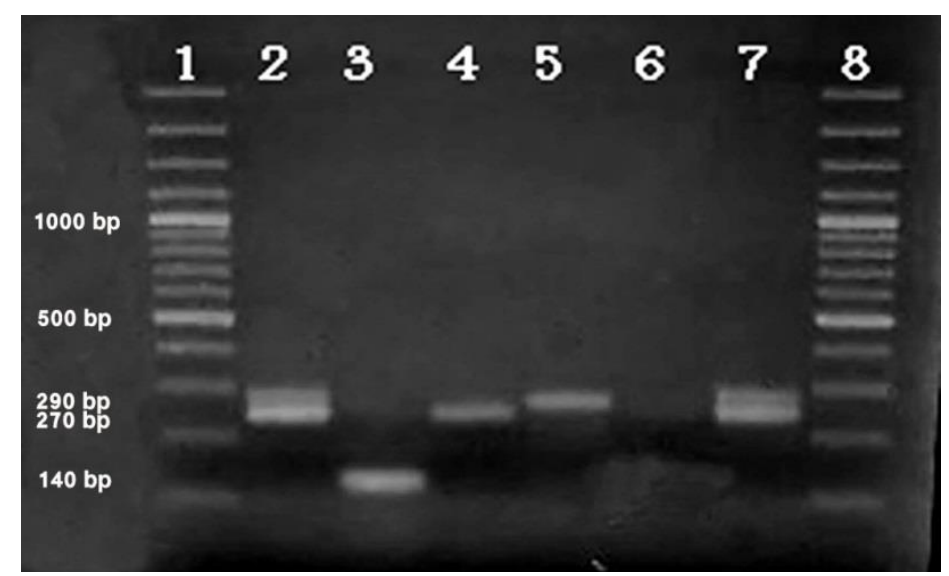

Fig.(2) illustrated the positive amplification of $140 \mathrm{bp}, 270 \mathrm{bp}$ and $290 \mathrm{bp}$ fragment spA gene from the extracted DNA of S.aureus isolated from quarter milk samples. ( clinical and subclinical isolates)

- Lane $1:$ (100 bp DNA ladder)

- Lanes 2 and 7: +ve clinical mastitis isolates with double specific bands (at $270 \mathrm{bp}$ and $290 \mathrm{bp}$.)

- Lane 3 : +ve isolates (+veCMT subclinical mastitis) with specific band (140 bp),

- Lane 4 : +ve isolate (+++ veCMT subclinical mastitis) with specific band (270 bp)

- Lane 5: +ve isolate (++ veCMT subclinical mastitis) with specific band (290 bp).

- Lane 6: -ve isolate for protein A (spA) gene ( +ve CMT subclinical mastitis )

- Lanes 8 : (100 bp DNA ladder) 


\section{DISCUSSION}

Bovine mastitis is an important and a persistent infection in the bovine population producing economic losses; drop in milk production, increased cost of treatment and culling process.

In the present work, the percentage of clinical mastitis was ( $19.5 \%$.) which agree with the finding of Petrovski et al (2009) . It seems that in Egypt there is high incidence of clinical mastitis compared to their finding, the high sample size and may be the herd area explains that low level of clinical mastitis in their situation .

As shown in Table (2), the percentage of subclinical mastitis according to C.M.T was ( $42.85 \%$ ) . High incidence of subclinical mastitis $(47.7 \%)$ was reported by El Gammal (2011). In other countries high figures of subclinical mastitis ranging from $(26.7 \%)$ to $(63.1 \%)$ have been reported by several authors (Chang et al, 2005 and Dego and Tareke, 2003). The high rate of subclinical mastitis can be explained by the fact that most cases of mastitis occur in subclinical forms, and the diseased animals continues for a time, to be a dangerous source of infection until increasing the clinical symptoms alert it to the dairy workers.

As shown in Tables (3) and (4) the percentage of S.aureus clinical mastitis was $(28.2 \%)$ while the percentage of S.aureus from subclinical mastitis was $(22.46 \%)$.
These results agreed with those of (Bedane et al 2012). S.aureus is responsible for approximately $30 \%$ to $40 \%$ of all mastitis cases. $S$. aureus can gain access to milk either by direct excretion from udders with clinical or subclinical staphylococcal mastitis or by contamination from the environment during handling and processing of raw milk (Scherrer et al, 2004).

In this study PCR protocol used for amplification and detection of $16 \mathrm{~S}$ rRNA genes of S.aureus isolates as a confirm diagnosis of these isolates; 10 isolates from 22 S.aureus isolated from clinical mastitis milk samples and 15 isolates from 31 S.aureus isolated from subclinical mastitis milk samples were subjected to PCR for detection of 16S rRNA gene and all $(100 \%)$ were +ve for that gene (Fig. 1) .These results agreed with those obtained by Løvseth et al (2004). 16S rRNA gene is speciesspecific gene used in identification of S.aureus (Monday and Bohach, 1999).

As shown in Table (5) PCR protocol used for amplification and detection of $\mathrm{X}$ region of protein $\mathrm{A}$ $(s p A)$ gene of S.aureus isolates to confirm the virulence of these isolates as the presence of protein $\mathrm{A}$ is an index of virulence; 10 isolates from 22 clinical mastitis milk specimens were subjected to PCR for detection of $\mathrm{X}$ region of protein A (spA) gene and all (100\%) were + ve . Also 19 isolates from 31 
subclinical mastitis milk specimens ( 5 isolates from 9 were +++ ve $\mathrm{CMT}$ and 10 isolates from 18 were ++ve CMT ) were subjected to PCR for detection of $\mathrm{X}$ region of protein A (spA) gene and all (100\%) were +ve. While the 4 isolates which were + ve CMT gave a result as one isolate positive PCR $(25 \%)$ and the 3 isolates were negative PCR of protein A (spA) gene . This results revealed that all clinical mastitis S.aureus samples which were subjected to PCR for detection of X region of protein A were $100 \%$ positive as well as higher degrees of subclinical mastitis samples . Figure (2) illustrated the positive amplification of $140 \mathrm{bp}, 270 \mathrm{bp}$ and $290 \mathrm{bp}$ fragment of $\mathbf{s p A}$ gene from the extracted DNA of S.aureus isolated from quarter milk samples(clinical and subclinical mastitis isolates). These results are agreed with those obtained by Akineden et al (2001).

Protein A displayed gene polymorphisms and allowed a genotypic characterization of the bacteria. The repetitive region $\mathrm{X}$ of the $(S p A)$ gene includes a variable number of 24-bp repeats. The number and sequence of individual repeats may differ among strains. The number of repeats has been related to the dissemination potential of $S$. aureus. Strains with more than seven repeats in the $X$ region tended to be epidemic, while the presence of seven or less repeats was indicative of a non-epidemic methicillin-resistant $\quad S$. aureus strain as reported by Erskine and Burton ( 2003), Salasia et al (2004) and Shanmugam et at (2007).

In this work results revealed that the relationship between $S$. aureus isolates and the grades of subclinical mastitis is statistically significant as much as the grade of subclinical mastitis increases the prevalence of $S$. aureus increases subsequently as showed in Table (6) and the results revealed also that the relationship between the virulence genes of S.aureus and the inflammation of udder in clinical mastitis as well as the high grades of subclinical mastitis is a positive relationship.

Finaly we concluded that S.aureus is one of the major bacterial causes of clinical and subclinical bovine mastitis. The relationship between protein A gene of S.aureus and the inflammation of udder in clinical mastitis as well as the high grades of subclinical mastitis is a positive relationship

\section{REFERENCES}

Akineden,O.; Annemüller, C.; Hassan, A. A.; Lämmler, C.; Wolter, W. and Zschöck doi, M. (2001): Toxin Genes and Other Characteristics of Staphylococcus aureus Isolates from Milk of Cows with Mastitis. ClinVaccine immune (8):5959-964

Bedane, A. ; Kasim, G.; Yohannis,T. ; Habtamu, T. ; Asseged, B. and Demelash, B. 
(2012): Study on Prevalence and Risk Factors of Bovine Mastitis in Borana Pastoral and Agro-Pastoral Settings of Yabello District, Borana Zone, Southern Ethiopia AmericanEurasian J. Agric. \& Environ. Sci., 12 (10): 1274-1281, 2012

Chang, B.S.; Bohach, G.A.; Lee, S.U.; Davis, W.C.; Fox, L.K.;Ferens,

Chowdhury, M.; Saha, G. R.; Chowdhury, J. and Das, S. K. (2005): Subclinical mastitis in crossbred cows. Journal of interacademicia 6 (special) 712715.

Dego, O.K. and Tareke, .F. (2003): Bovine mastitis in selected areas of southern Ethiopia.Trop Anim Health Prod.;35(3):197-205.

El Gammal, A.M. (2011): Molecular typing of exotoxines genes in S.aureus isolates . Ph.D Theses in Microbiology. Department of Bacteriology - ImmunologyMycology. Fac.Vet.Med. Suez Canal Uni

Erskine, R.J and Burton, J.L. (2003): Immunity and mastitis. Some new ideas for an old disease. Vet. Clin. North Am. Food Anim. Pract. 19, 1-45

Fitzgerald, J.R.; Hartigan, P.J.; Meaney, W.J. and Smyth, C.J. (2000): Molecular population and virulence factor analysis of Staphylococcus aureus from bovine intramammary infection. J Appl Microbiol, 88: 1028-1037
Foster, T.J. (2005): Immune evasion by Staphylococci. Nat Rev Microbiol, 3: 948-958.

Gao, J. and Stewart, G.C. (2004): Regulatory elements of the Staphylococcus aureus protein A (Spa) promoter. J Bacteriol, 186: 3738-3748

Kalorey, D.R.; Yuvaraj Shanmugam, N.; Vasantrao, K.; Kapil, K.C. and Sukhadeo, B. B. (2007): PCR-based detection of genes encoding virulence determinants in Staphylococcus aureus from bovine subclinical mastitis cases .J Vet Sci. 2007 June; 8(2): 151-154.

Løvseth, A.; Loncarevic, S. and Berdal, K. G. (2004): Modified Multiplex PCR Method for Detection of Pyrogenic Exotoxin Genes in Staphylococcal Isolates. J. Clinic. Microbiol.; 42.( 8) :38693872.

Monday, S. R., and Bohach, G. A. (1999): Use of multiplex PCR to detect classical and newly described pyrogenic toxin genes in staphylococcal isolates. J. Clin. Microbiol.; 37:3411-3414.

Petersson-W. C. S., and Mullarky I. K. (2010): S.aureus Mastitis: Cause, Detection, and Control 404-229 June 11, 2010,

Petrovski, K.R.; Heuer, C.; Parkinson, T.J. and Williamson, N.B. (2009): The incidence and aetiology of clinical bovine mastitis on 14 farms in Northland, New Zealand. N Z Vet J. 2009 Apr;57(2):109-15. 
Quinn, P. J.; Carter, M. E.; Makrkey, B. K. and Carter, G. R. (1994): Clinical veterinary microbiology.mosby year book Europ Limited, Lynton House,London,. 109-126.

Salasia, S.I.; Khusnan, Z.; Lammler, C. and Zschock, M. (2004):Comparative studies on pheno- and genotypic properties of S.aureus isolated from bovine subclinical mastitis in central Java in Indonesia and Hesse in Germany. J Vet Sci. 2004 Jun;5(2):103-109.

Scherrer, D.; Corti, S.; Muehlherr, J. E.; Zweife, C. and Stephan, R. (2004): Phenotypic and genotypic characteristics of $S$. aureus isolates from raw bulk-tank milk samples of goats and sheep. Veterinary Microbiology ; 101 :101107.
Shanmugam, Y.; Kalorey, D.R.; Kurkure, N.V.; Chousalkar, K.K. and Barbuddhe, S.B. (2007): PCR-based detection of genes encoding virulence determinants in S.aureus from bovine subclinical mastitis cases. J Vet Sci 2007 Jun;8(2):151-154. .

Singh, R.S. and Bansal, B.K. (2004): Variation in selected components of milk among different milk fractions and its relevance to diagnosis of mastitis in buffaloes. Buffalo Journal, 3: 213224.

Van Eys, G.M.; Gravekamp, C.; Gerritsen, M.; Quint, W.; Cornlissen, S.J. and Terpstra, W.(1989): Detection of leptospira in urine by PCR.j.clinc.microbiol.27:22582262.

$$
\begin{aligned}
& \text { توصيف المظهري والجينى للمكور العنقودي الذهبي من التهاب الضرع البقري الاكلينيكي }
\end{aligned}
$$

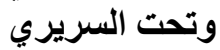

$$
\begin{aligned}
& \text { محمد السيد عنانى , **سهى عز الدين يونس, عبد العظيم محمد , *محمد سالم , هاى عبد }
\end{aligned}
$$

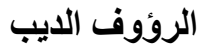

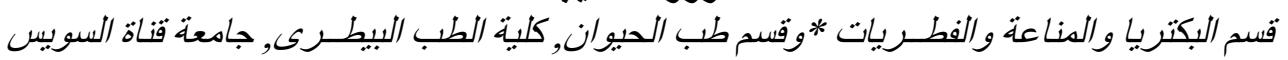

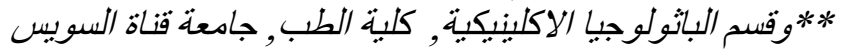

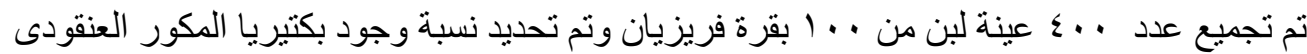

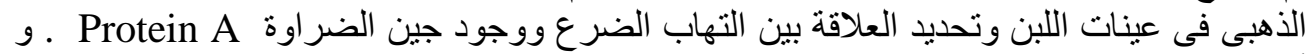

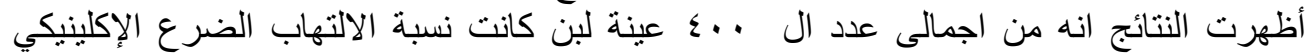
19.5\% ونسبة التهاب الضرع السريري بعد تشخيصه باستخدام اختبار الكاليفورنيا

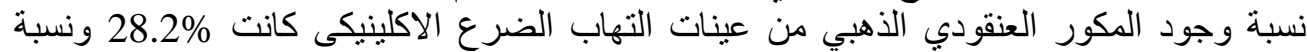

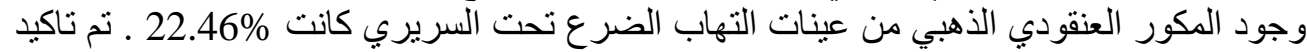

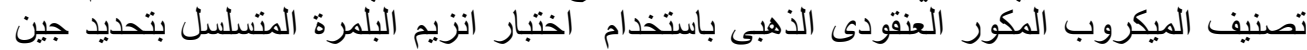

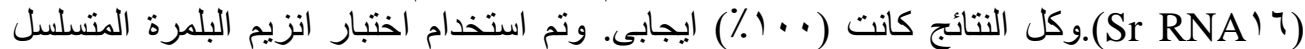

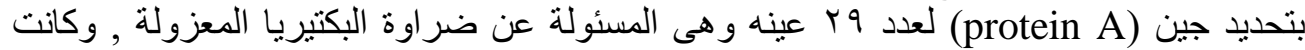

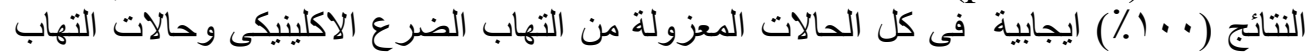

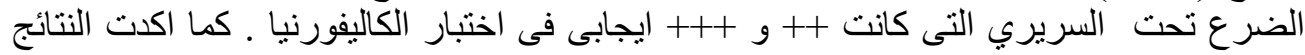
على وجودعلاقة ايجابية بين التهاب الضر عانت ووجود جين الضراوة Protein A. 